\title{
Does Service Innovation Act as a Mediator in Differentiation Strategy and Organizational Performance Nexus? An Empirical Study
}

\author{
Narentheren Kaliappen ${ }^{1} \&$ Haim Hilman ${ }^{2}$ \\ ${ }^{1}$ Othman Yeop Abdullah Graduate School of Business, Universiti Utara Malaysia, Malaysia \\ ${ }^{2}$ Institute of Quality Management, Universiti Utara Malaysia, Malaysia \\ Correspondence: Narentheren Kaliappen, Othman Yeop Abdullah Graduate School of Business, Universiti Utara \\ Malaysia, Malaysia. E-mail: s93697@student.uum.edu.my
}

$\begin{array}{lr}\text { Received: March 11, } 2014 & \text { Accepted: April 17, } 2014 \quad \text { Online Published: May 30, } 2014 \\ \text { doi:10.5539/ass.v10n11p123 } & \text { URL: http://dx.doi.org/10.5539/ass.v10n11p123 }\end{array}$

\begin{abstract}
The study determines how service innovation impacts differentiation strategy and the impact on organizational performance. The target population of this research was 475 hotels, which are three to five star hotels in Malaysia. Due to the small population and the nature of the research, questionnaires were sent by mail and email to all the targeted three to five star hotels' managers. Regression was used to analyse the relationship of differentiation strategy, service innovation and organizational performance. The result shows that differentiation strategy has a significant effect on organizational performance and service innovation has a significant effect on organizational performance. Remarkably, this study found that service innovation partially mediates the relationship of differentiation strategy and organizational performance. This study found that hoteliers that pursuing a differentiation strategy should simultaneously employ service innovation to attain better organizational performance. Thus, this study contributes a significant knowledge to the Malaysia hotel industry. This study fills in some of the gap and showing the significance of differentiation strategy and service innovation in the hotel industry which has received little empirical attention in current strategic management literatures. It also offers some practical contributions to the development of service innovation in relation to differentiation strategy and organizational performance.
\end{abstract}

Keywords: differentiation strategy, service innovation, organizational performance, Malaysia hotel industry

\section{Introduction}

Existing latest advanced technologies and shifting market environment made efficient strategic implementation as a fundamental requirement for every organization (Kaliappen \& Hilman, 2013; Wang, Chen \& Chen, 2012; Olsen \& Connolly, 2000). Specifically, the growing of the hotel industry has seen rivalry progressively increase and guests become gradually classy (Wang et al., 2012). To strive, hotels need an efficient strategic implementation that could transform overall strategic direction to encounter the requirements of the changing marketplace (Okumus, 2003). Hotels in the hunt for developing their performance cannot merely depend on the effectiveness of business strategy, but need to create an operative functional strategy that could well integrate to produce better outcomes. So, this study emphasises differentiation strategy as a business strategy in competing against rivals in the industry. Besides differentiation strategy, hoteliers today cannot escape from service innovation that assists to make enrichment to uphold the existing market and acquire new business. Indeed, equally differentiation strategy and service innovation are linked to the outcome of organizations. It has already been established that the differentiation strategy and service innovation could improve organizational performance (Hilman, 2009; Grawe, Chen \& Daugherty, 2009; Allen \& Helms, 2006; Frohwein \& Hansjurgens, 2005). Many studies also have shown that effective differentiation strategy and service innovation will lead to create competitive advantage and becoming crucial for service organizations in fulfilling the customers' requirements. But, prior studies did not look at the link between differentiation strategy, service innovation and performance of hotels in Malaysia. This paper tried to fill that gap by conceptualizing service innovation as a mediator in the differentiation strategy and performance relationship.

Thus, the present study incorporated differentiation strategy and service innovation for improving organizational performance. Therefore, this study developed two objectives; (1) to observe the relationship of differentiation strategy and organizational performance and (2) to examine the impact of service innovation in mediating the 
association of differentiation strategy and organizational performance.

\section{Literature Review}

In this study, the researchers scrutinised the arrangement of service innovation and differentiation strategy, hence assisting to recognise in what manner service innovation abilities should be used to reach hotels strategic objectives (Projogo \& Sohal, 2006). This study emphasised vertical strategic alignment between business strategy and functional strategy. Many prior studies linked functional strategies to business performance (Gyamph \& Acquaah, 2008; Frambach, Prabhu \& Verhallen, 2003; Lukas, 1999). This study adopts strategy implementation perspective which emphasises that strategy has a stronger effect on structure rather than structure influencing strategy. However, very few studies specifically investigate the linkage of the above mentioned strategies from the strategic implementation perspective and strategic alignment in the context of Malaysia hotel industry.

\subsection{Differentiation Strategy}

Hilman, Mohamed, Othman \& Uli (2009) stated that the organization which pursued differentiation tend to establish differences in various dimensions in order to make buyers to perceive differences between their offerings and competitors ones. Differentiation is relatively about offering superior, different and unique product / service to the customers (Venu, 2001; Hyatt, 2001; Porter, 1980). Organizations which adopt differentiation tend to charge a higher price for the offerings than their competitors due to the unique features, cost of delivery system, service quality and distribution channels (Lo, 2012; Hilman et al., 2009; Venu, 2001; Porter, 1980). According to Bordean, Borza, Nistor \& Mitra (2010) hotels can achieve the uniqueness through several activities, namely service innovation, superior service and creative advertisement. Frohwein \& Hansjurgens (2005) suggested that the organizations implementing differentiation tends to focus on product / service innovation. Furthermore, Prajogo \& Sohal (2006) stated that there is an association between differentiation and product / service innovation.

\subsection{Service Innovation}

O'Sullivan \& Dooley (2009) defined service innovation as making beneficial changes in the service that the customers use. Specifically, service innovation occurred due to a higher degree of customer interaction and active demand from the customers. Thus, an organization needs to continually perform innovation in service in order to increase the features of services to meet the customer's requirement (O'Sullivan \& Dooley, 2009). Crucially, service innovation has also been referred as product innovation (Damanpour \& Gopalakrishnan, 2001). Based on Chen (2011) service innovation is considered as the development of new and useful ideas to improvise service effectively. Victorino, Verma, Plaschka \& Dev (2005) stated that it is beneficial to implement service innovation in the hospitality industry. Generally, customers can simply find substitutable service offers in hospitality industry, therefore in order to avoid this challenge the hoteliers should offer new and innovative service to the customers based on their preferences, quality and technological interface in order to gain sustainable competitive advantage (Victorino et al., 2005). In addition, Kumar, Jones, Venkatesan \& Leone (2011) mentioned that the organization could develop product / service innovation in order to respond to customers' insights and this will assist to advance the business performance. For instance, hoteliers may offer service innovation such as diverse and delicious menu, in-room speed internet service, WI-Fi facilities and wireless technology, customization of room decoration, unique room facilities, and in-room kitchenettes and bathroom facilities, creative design and architectural practices (Victorina et al., 2005). Basically, the intention to perform service innovation is to provide new offerings to customers to meet their needs. The arguments clearly indicate similar characteristics between differentiation and service innovation, but very limited empirical evidence validates the above mentioned associations.

\subsection{Performance Measurement}

Research on organizational performance is not relatively new; it has been extensively studied by many researchers and scholars as a dependent variable. Wadongo, Odhuno, Kambona \& Othuan (2010) mentioned that, earlier performance measurement has been measured by short term financial and accounting measures. Later, Vengkataraman \& Ramanujam (1986) reviewed 10 different types of measurements and established 3 performance measurement dimensions, namely financial performance, business performance and organizational effectiveness. Crucially, Atkinson \& Brander- Brown (2001) indicated that the majority of hotels emphasised more on financial performance measurement (profitability) and very less or no attention given to non - financial performance indicators.

In general, there were several shortcomings in financial performance measurement such as limited accuracy, 
neutrality, summarized and irrelevant due to accounting period delay (Wadongo et al., 2010). In addition, financial measurement concerned only on a short term basis, unbalanced and also failed to reflect the strategic issues and performance (Wadongo et al., 2010; Harris \& Mongiello, 2001; Kaplan \& Norton, 1992, 1996). Due to several weaknesses in measuring organizational performance by financial measure alone, many researchers tend to evaluate the performance using both financial and non-financial performance indicators (Wadongo et al., 2010; Hilman, 2009; Razalli, 2008; Jusoh and Parnell, 2008; Evans, 2005). Prior literatures indicated that non-financial performance measures were necessary for the hospitality industry because they improved the performance by identifying managerial activities and dealing with causes instead of effects within a service environment which cannot be obtained from financial measurement alone (Arias-Aranda, 2003).

The balanced scorecard (BSC) performance measurement is the most popular, least criticized, widely accepted and implemented a performance measurement tool which created by Kaplan and Norton (Paranjape, Rossiter \& Pantano, 2006; Evans, 2005). So, BSC was created to provide balanced performance measurement for financial and non- financial perspectives in assessing the organizational performance. Therefore, BSC retained the financial measures and added three non- financial perspectives, namely customer, internal process and learning and growth (Kaplan \& Norton, 1992, 1996).

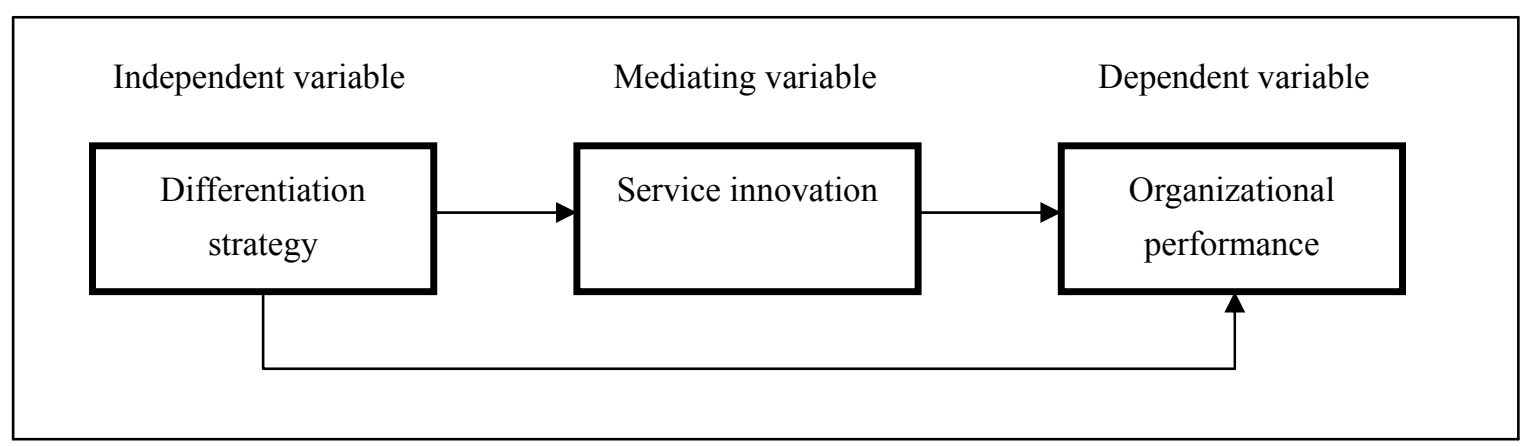

Figure 1. Conceptual framework

The framework presented in figure 1 proposes that organizational performance is directly affected by differentiation strategy and service innovation. Organizational performance is also affected indirectly by differentiation strategy through service innovation. So, service innovation may mediate the association of differentiation strategy and organizational performance. This association is suggested due to if hoteliers to be efficacious in cultivating their performance there must be steadiness between differentiation strategy and service innovation (Projogo \& Sohal, 2006). Finally, the framework suggests that differentiation strategy has an impact on service innovation.

\subsection{Hypotheses Development}

Service innovation is as one of the functional strategies that could align with differentiation strategy (Frohwein \& Hansjurgens, 2005). Put it differently, service innovation enhances the essence to differentiation strategy. The strategic role of functional strategies will be an important consideration in fierce global competition and depend on the chosen business strategy (Gyampah \& Acquaah, 2008). Previous studies of Projogo (2006) have emphasised that service innovation purpose must match with the overall business strategy. Precisely, they discovered that business units that follow advance differentiation would also tend to emphasise service innovation and customer focus to avoid mismatching of strategies. The arguments and the existing literatures on service innovation indicate a strong connection occurs between service innovation and differentiation strategy (Projogo \& Sohal, 2006; Miller, 1988).

H1: Differentiation strategy influences service innovation.

The innovation literature has suggested a direct link of service innovation and organizational performance (Grawe et al., 2009). Service innovation offers new service related to the firm's existing offerings (Schilling \& Werr, 2009; Chesbrough, 2004). The value added nature of service innovations could permit a firm to enter into new markets and grasp new customers (Victorina et al., 2005). Firms displaying service innovation can achieve better organizational performance (Mansury \& Love, 2005).

$\mathrm{H} 2$ : Service innovation has a positive impact on performance.

Firm used differentiation strategy to establish several differences that could be difficult to be imitated by 
competitors (Hilman, 2009; Porter, 1980, 1985). Furthermore, it will assist to set the mind of customers to perceive that the service has unique features (Hyatt, 2001). Normally, firms have successfully created differentiation though brand image, innovative features, service flexibility, quality and compatibility (Allen \& Helms, 2006; McCracken, 2002). The ultimate reason firms choose differentiation is to satisfy the customers' needs and desires, create customers' loyalty and enhance performance (Porter, 1980).

H3: Differentiation strategy has a positive impact on performance.

Previously, we explained about strategic implementation and strategic alignment on the need for congruence between organizations' differentiation strategy and its service innovation. A differentiation strategy that is accurately supported by service innovation is anticipated to improve performance due to the decisions made by service innovation functions will be designed towards the attainment of the differentiation strategy objectives (Projogo, 2006; Frohwein \& Hansjurgens, 2005). A firm is anticipated to select an apt business strategy (differentiation) to reach greater performance. Porter (1980) said that strategic choice without good strategic implementation cannot assure higher performance attainment. In hospitality setting, the execution of differentiation strategy should be linked to service innovation that lets the hoteliers to understand the guests and attain superior performance. If a firm denies the imperative link of differentiation strategy and service innovation, it perhaps dearth in producing innovative services, unable to satisfy the customers and achieve strategic goals.

H4: The influence of differentiation strategy on performance through service innovation will be better than the direct effect of differentiation strategy on performance.

\section{Methodology}

\subsection{Variables}

The independent variable of the study is differentiation strategy. The variable was measured by a seven point Likert scale, ranging from 1 (strongly disagree) to 7 (strongly agree). The mediation variable of the study is service innovation. The variable was measured by a seven point Likert scale, ranging from 1 (strongly disagree) to 7 (strongly agree). Present study used subjective views of respondents to evaluate the organizational performance. So the respondents were inquired to assess both financial and non-financial performance in BSC setting of their hotel's within the past five years on a scale of 1 (decrease significantly) to 7 (increase significantly). The number of items and their references are presented in Table 1.

Table 1. Research Instrumentation and measurement

\begin{tabular}{|c|c|c|c|}
\hline Variables & $\begin{array}{l}\text { No of } \\
\text { items }\end{array}$ & Measures & Reference \\
\hline Differentiation strategy & 7 & $\begin{array}{ll}\text { - } & \text { Introducing new service quickly } \\
\text { - } & \text { Provide different services } \\
\text { - } & \text { Offer broader range of service } \\
\text { - } & \text { Improving the service providing time } \\
\text { - } & \text { Provide high quality services } \\
\text { - } & \text { Customizing the services } \\
\text { - } & \text { Provide after sales service and customer support }\end{array}$ & Auzair (2011) \\
\hline Service innovation & 5 & $\begin{array}{l}\text { - } \text { Accept service innovation in project management } \\
\text { - } \quad \text { Give special emphasis on service innovation } \\
\text { - } \quad \text { Always seeking innovative features } \\
\text { - Change the existing services to meet exclusive } \\
\text { requirement } \\
\text { - Come up with new service offerings }\end{array}$ & $\begin{array}{l}\text { Grawe et al. } \\
(2009)\end{array}$ \\
\hline $\begin{array}{l}\text { Organizational } \\
\text { performance }\end{array}$ & 6 & $\begin{array}{ll}\text { - } & \text { Return on Investment (ROI) } \\
\text { - } & \text { Market share } \\
\text { - } & \text { Sales growth } \\
\text { - } & \text { Customer perspective } \\
\text { - } & \text { Internal process perspective } \\
\text { - } & \text { Learning and growth perspective }\end{array}$ & $\begin{array}{l}\text { Hilman (2009), } \\
\text { Kaplan and } \\
\text { Norton } \\
(1996)\end{array}$ \\
\hline
\end{tabular}




\subsection{Sample and Data Collection}

Data was acquired through a census method on 475 hotels' top or middle managers who have extensive understanding of business and functional strategies of their hotel. Due to the small population and the nature of the research, questionnaires were sent by mail and email to all the targeted three to five star rated hotels which are registered under directory of Ministry of Tourism and Culture, Malaysia. Of these questionnaires, only 60 usable responses were returned, reflecting $12.6 \%$ response rate.

\subsection{Findings}

The validity of the constructs was inspected earlier to hypothesis analysis. Even if, the components of differentiation strategy, service innovation and organizational performance are well-known, but still exploratory factor analysis (EFA) was carried out. Principal component analysis (PCA) used to assess the variables. All the items were remained due to strong loadings, greater than 0.50 (Hair, Black, Babin \& Anderson, 2010). The findings of EFA are presented in Table 2. To check the reliability of the data, Cronbach's alpha was executed. The alpha values of these factors were greater than 0.80 as shown in Table 2. Thus, this indicates strong validity and reliability has been achieved.

Table 2. Results of validity and reliability

\begin{tabular}{llll}
\hline Variables & No of items & Factor loadings & Alpha \\
\hline Differentiation strategy & 7 & $0.722-0.835$ & 0.90 \\
Service innovation & 5 & $0.784-0.859$ & 0.89 \\
Organizational performance & 6 & $0.645-0.824$ & 0.84 \\
\hline
\end{tabular}

To achieve the objectives developed, the Preacher \& Hayes (2004) simple mediation procedure were used. The findings were presented in the following tables. Table 3 presents the mean and standard deviation of all variables and inter-correlations.

Table 3. Descriptive statistics and inter-correlations

\begin{tabular}{lcclll}
\hline Variables & Mean & SD & $\begin{array}{l}\text { Organizational } \\
\text { performance }\end{array}$ & $\begin{array}{l}\text { Differentiation } \\
\text { strategy }\end{array}$ & $\begin{array}{l}\text { Service } \\
\text { innovation }\end{array}$ \\
\hline $\begin{array}{l}\text { Organizational } \\
\text { performance }\end{array}$ & 3.746 & 2.660 & 1.000 & & \\
Differentiation strategy & 3.123 & 2.067 & $0.979^{*}$ & 1.000 & \\
Service innovation & 3.288 & 2.219 & $0.986^{*}$ & $0.981^{*}$ & 1.000 \\
\hline
\end{tabular}

Note: Significant at: $* \mathrm{p}<0.01$

It can be observed from the table 4 that differentiation strategy has a significant effect on organizational performance $(\mathrm{B}=1.261, \mathrm{p}<0.01)$. Differentiation strategy also has a significant influence on service innovation $(B=1.054, p<0.01)$. The result also indicated that service innovation has a significant impact on organizational performance $(B=0.776, p<0.01)$. Finally, the association of differentiation strategy and organizational performance after the direct effect of service innovation on organizational performance was controlled indicate $(B=0.444, p<0.01)$. Differentiation strategy still has a significant influence on organizational performance, although it reduced from $\mathrm{B}=1.261$ to 0.444 . This indicates partial mediation.

Table 4. Outcomes of direct and total effects

\begin{tabular}{lllll}
\hline Variables & Coefficient (B) & S.E & $\mathrm{t}$ & Sig \\
\hline OP*DIF & 1.261 & 0.024 & 51.952 & 0.000 \\
SI*DIF & 1.054 & 0.020 & 53.894 & 0.000 \\
OP*SI.DIF & 0.776 & 0.092 & 8.433 & 0.000 \\
OP*DIF.SI & 0.444 & 0.099 & 4.490 & 0.000 \\
\hline
\end{tabular}




\section{Discussion}

This study proposed four hypotheses. The outcomes supported all the propositions. This study showed that differentiation strategy positively affects service innovation. These results supported the prior notion of Projogo \& Sohal (2006) and Frohwein \& Hansjurgens (2005). These may be that hotels implementing differentiation strategy could strengthen their unique service creation, altering business design and swiftly reacting to customers' reaction and needs. The literatures exposed that a dearth of inquiries on the links between differentiation strategy and service innovation in the hotel industry particularly in Malaysia. Present study established that differentiation strategy is an antecedent of service innovation. Service innovation mediated the connection of differentiation strategy and organizational performance. Hence, differentiation strategy facilitated to cultivate service innovation capabilities to identify gaps in market offerings, provide new opportunities, new service development, customer satisfaction or supports and continuous innovative services. Service innovation plays a significant role as a functional strategy that improving hotel performance (Ooncharoen \& Usshawanitchakit, 2009). The results indicated that the influence of differentiation strategy on performance was greater in the occurrence of service innovation. This result supported the notion of Porter (1980) who emphasises the significance of strategic selection and implementation in creating better performance. The study showed that pursuing a differentiation strategy with close coordination of service innovation provided an optimistic effect on performance.

\subsection{Implications}

Differentiation and service innovation are crucial strategic factors for every hotel. In order to be competitive, hoteliers must pursue differentiation strategy as their business strategy where the previous studies show a positive link with organizational performance. Hotels that pursue differentiation strategy are likely to improve their service innovation capacity and performance. It is recommended that managers who, desiring to improve the performance of their hotels must strategically align their business strategy (differentiation strategy) with functional strategy (service innovation) in their business model. This study also provided evidence that efficient service innovation would have the greatest impact on organizational performance. It is believed that the top and middle managers in the Malaysia hotel industry could benefit from the findings by realising the importance of strategic alignment and implementation of differentiation and service innovation strategies. Knowledge that gained from this study could provide hotel managers with an enhanced ability to make strategic decisions for future development. This finding has suggested that service innovation should be incorporated as a strategic tool to evaluate differentiation effort in the hotel industry. This can be used in shaping the effectiveness of the hotel's differentiation strategy in achieving superior performance.

\subsection{Limitations and Future Recommendations}

There are several limits that should be admitted. The data utilised in this study gathered with subjective approach that is based on the opinions of hotel managers. Though, perceptual facts are widely utilised in strategic management studies, but still there is a chance to occur bias in the findings. In addition, the responses came from single respondents (managers). So, it suggested that further study can divide the survey instrument to be completed by various department managers separately to avoid respondent bias and measurement error. Many firms have successfully implemented managerial capabilities, technological capabilities, marketing capabilities, competitive priorities, strategic flexibilities and sourcing activities that improve performance (Naqshbandi \& Idris, 2012; Parnell, 2011; Hilman \& Mohamed, 2011; Gyampah \& Acquaah, 2008; Javalgi, Whipple \& Ghosh, 2005). However, the questions of how above mentioned strategic factors could well align with Malaysia hotels' business strategies are still vague. Thus, further investigation in these areas could help to enrich the existing theory. This study used cross sectional survey method. Do the differentiation strategy and service innovation, influence long term organizational performance? This research question offers a greater chance for longitudinal studies. So, recommending future research should concentrate more on longitudinal survey method.

\section{Conclusion}

A vital aspect of strategic alignment and execution is the effective transmission of business strategy's goals into functional strategies. So, this study presented how hoteliers could achieve their strategic business objectives by synchronising the functional activities that in turn advance performance. Therefore, this study found strong association of differentiation strategy and service innovation. Besides, the study established that service innovation partially mediates the link of differentiation strategy and organizational performance. It can be said that, differentiation strategy would enhance better performance if the hotels execute efficient service innovation as their functional strategy. To sum up, service innovation does act as a mediator in differentiation strategy and organizational performance nexus in the context of Malaysia hotel industry. 


\section{References}

Allen, R., \& Helms, M. (2006). Linking strategic practices and organizational performance to Porter's generic strategies. Business Process Management Journal, 12(4), 433-454. http://dx.doi.org/10.1108/14637150610678069

Arias-Aranda, D. (2003). Service operation strategy, flexibility and performance in engineering consulting firms. International Journal of Operation and Production Management, 23(11). 1402-1421. http://dx.doi.org/10.1108/01443570310501907

Atkinson, H., \& Brander- Brown, J. (2001). Rethinking performance measures: assessing progress in UK hotels. International Journal of Contemporary Hospitality Management, 13(3). http://dx.doi.org/10.1108/00251740610715740

Auzair, S. (2011). The effect of business strategy and external environment on management control system: A study of Malaysian hotels. International Journal of Business and Social Science, 2(13), 236-244.

Bordean, O., Borza, A., Nistor, R., \& Mitra, C. (2010). The use of Porter's generic strategies in Romanian hotel industry. International Journal of Trade, Economics and Finance, 1(2).

Chen, W. J. (2011). Innovation in hotel services: Culture and personality. International Journal of Hospitality Management, 30(1). http://dx.doi.org/10.1016/j.ijhm.2010.07.006

Chesbrough, H. (2004). A failing grade for the innovation academy. Financial Times. Retrieved from http://news.ft.com/home/us

Damanpour, F., \& Gopalakrishnan, S. (2001). The dynamics of the adoption of product and process innovation in organizations. Journal of Management Studies, 38(1). http://dx.doi.org/10.1111/1467-6486.00227

Evans, N. (2005). Assessing the BSC as a management tool for hotel. International Journal of contemporary hospitality, 17(5), 376-390. http://dx.doi.org/10.1108/09596110510604805

Frambach, R., Prabhu, J., \& Verhallen, T. (2003). The influence of business strategy on new product activity: The role of market orientation. International Journal of Research in Marketing, 20(4), 377-397.

Frohwein, T., \& Hansjurgens, B. (2005). Chemicals regulation and the Porter hypothesis: A critical review of the new European chemical regulation. Journal of Business Chemistry, 2(1), 19-36.

Grawe, S., Chen, H., \& Daugherty, P. (2009). The relationship between strategic orientation, service innovation on performance. International Journal of Physical Distribution and Logistics Management, 39(4), 282-300. http://dx.doi.org/10.1108/09600030910962249

Gyampah, K. A., \& Acquaah, M. (2008). Manufacturing strategy, competitive strategy and firm performance: An empirical study in a developing economy environment. International Journal of Production Economics, 111, 575-592. http://dx.doi.org/10.1016/j.ijpe.2007.02.030

Hair, J. F., Black, W. C., Babin, B. J., \& Anderson, R. E. (2010). Multivariate Data Analysis (7th ed.). Prentice Hall, Upper Saddle River, New Jersey.

Harris, P., \& Mongiello, M. (2001). Key performance indicators in European hotel property: General Manager's choice and company profiles. International Journal of Contemporary Hospitality Management, 13(3), 120-128. http://dx.doi.org/ 10.1108/09596110110388909

Hilman, H. (2009). Relationship of competitive strategy, strategic flexibility and sourcing strategy on organizational performance. Unpublished PhD Dissertation. Universiti Putra Malaysia.

Hilman, H., \& Mohamed, Z. A. (2011). Sourcing strategies, practices and effects on organizational performance. Journal of Global Business Advancement, 4(1), 18-31. http://dx.doi.org/10.1504/JGBA.2011.040332

Hilman, H., Mohamed, Z. A., Othman, R., \& Uli, J. (2009). The effect of sourcing strategies on the relationship between competitive strategy and firm performance. International Review of Business Research Papers, 5(3), 346-361.

Hyatt, L. (2001). A simple guide to strategy. Nursing Homes, 50(1), 12-13.

Javalgi, R, Whipple, T., Ghosh, A., \& Young, R. (2005). Market orientation, strategic flexibility, and performance: Implications for services providers. Journal of Services Marketing, 19(4), 212-221. http://dx.doi.org/10.1108/08876040510605244

Jusoh, R., \& Parnell, J. A. (2008). Competitive strategy and performance measurement in the Malaysian context. 
Management decision, 46(1), 5-31. http.dx.doi.org/10.1108/00251740810846716

Kaliappen, N., \& Hilman, H. (2013). Enhancing organizational performance through strategic alignment of cost leadership strategy and competitor orientation. Middle-East Journal of Scientific Research, 18(10), 1411-1416. http://www.idosi.org/mejsr/mejsr18(10)13/6.pdf

Kaplan, R. S., \& Norton, D. P. (1992). The Balanced Scorecard: Measures that Drive Performance. Harvard Business Review, 70(1), 71-79.

Kaplan, R. S., \& Norton, D. P. (1996). The Balanced Scorecard: Translating Strategy into Action. Boston: HBS Press.

Kumar, V., Jones, E., Venkatesan, R., \& Leone, R. P. (2011). Is market orientation a source of sustainable competitive advantage or simply the cost of competing? Journal of Marketing, 75, 16-30.

Lo, Y. H. (2012). Back to hotel strategic management 101: An examination of hotel's implementation of Porter's generic strategy in China. The Journal of International Management Studies, 7(1), 56-69.

Lukas, B. A. (1999). Strategic type, market orientation, and the balance between adaptability and adaptation. Journal of Business Research, 45(2), 147-156.

Mansury, M. A., \& Love, J. H. (2008). Innovation, productivity and growth in US business services: A firm level analysis', Technovation, 28(1-2), 52-62. http://dx.doi.org/10.1016/j.technovation.2007.06.002

McCraken, L. (2002). Differentiation: Win New Business with Less Effort. Principle’s Report, 2(4), 1.

Miller, D., (1988). Relating Porter's business strategies to environment and structure: Analysis and performance implications. Academy of Management Journal, 31, 280-308.

Naqshbandi, M. M., \& Idris, F. (2012). Competitive priorities in Malaysia service industry. Business Strategy Series, 13(6), 263-273. http://dx.doi.org/10.1108/17515631211286100

Okumus, F. (2003). A framework to implement strategies in organizations. Management Decision, 41(9), 871882. http://dx.doi.org/10.1108/00251740310499555

Olsen, M. D., \& Connolly, D. J. (2000). Experience-based travel. Cornell Hotel and Restaurant Administration Quarterly, 41(1), 30-40.

Ooncharoen, N., \& Usshawanitchakit, P. (2011). Service innovation strategy of hotel businesses in Thailand: An inductive approach. International Journal of Strategic Management and International Academy of Business and Economy. Retrieved from http://www.highbeam.com

O'Sullivan, D., \& Dooley, L. (2009). Applying innovation. Thousand Oaks, CA: SAGE Publications, Inc. http://dx.doi.org/10.4135/9781452274898

Paranjape, B., Rossiter, M., \& Pantano, V. (2006). Insight from balanced scorecard performance measurement system: Successes, failure and future- A review. Measuring Business Excellence, 10(3), 4-14.

Parnell, J. A. (2011). Strategic capabilities, competitive strategy and performance among retailers in Argentina, Peru and The United States. Management Decision, 49(1), 130-155. http://dx.doi.org/10.1108/00251741111094482

Porter, M. E. (1980). Competitive strategy. New York: Free Press.

Porter, M. E. (1985). Competitive advantage: Creating and sustaining superior performance. New York. Free Press.

Prajogo, D. I. (2006). The relationship between innovation and business performance: A comparative study between manufacturing and service firms. Knowledge and Process Management. 13(3), 218-225. http://dx.doi.org/10.1002/kpm.259

Prajogo, D. I., \& Sohal, A. S. (2006). The relationship between organizational strategy, total quality management and organizational performance: Mediating role of TQM. European Journal of Operational Research, 168, 35-50. http://.dx.doi.org/10.1016/j.ejor.2004.03.033

Preacher, K. J., \& Hayes, A. F. (2004). SPSS and SAS procedures for estimating indirect effects in simple mediation models. Behavior Research Methods, Instruments, \& Computers, 36, 717-731.

Razalli, M. R. (2008). The consequences of service operations practice and service responsiveness on hotel performance: Examining hotels in Malaysia. Unpublished $\mathrm{PhD}$ Dissertation.

Schilling, A., \& Werr, A. (2009). Managing and organizing for innovation in service firms: A literature review 
with annotated bibliography. VINNOVA Report.

Venkatraman, N., \& Ramanujam, V. (1986). Management of organizational performance in strategy research: A comparison of approaches. Academy of Management Review, 11(4), 801-814.

Venu, S. (2001). India: Competitive advantage: Alternative scenarios. Businessline, 12(1).

Victorino, L., Verma, R., Plaschka, G., \& Dev, C. (2005). Service innovation and customer choices in the hospitality industry. Managing Service Quality, 15(6), 555-576. http://dx.doi.org/10.1108/09604520510634023

Wadongo, B., Odhuno, E., Kambona, O., \& Othuan, L. (2010). Key performance indicators in the Kenyan hospitality industry: A managerial perspective. Benchmarking: An International Journal, 17(6), 858-875. http://dx.doi.org/ 10.1108/14635771011089764

Wang, C. H., Chen, K. Y., \& Chen, S. C. (2012). Total quality management, market orientation and hotel performance: The moderating effects of external environmental factors. International Journal of Hospitality Management, 31(1), 119-129. http://dx.doi.org/10.1016/j.ijhm.2011.03.013

\section{Copyrights}

Copyright for this article is retained by the author(s), with first publication rights granted to the journal.

This is an open-access article distributed under the terms and conditions of the Creative Commons Attribution license (http://creativecommons.org/licenses/by/3.0/). 